\title{
Study of Some Haematological and Serum Protein of African Catfish (Clarias Gariepinus) Juveniles Fed with Chromoleana Odorata as Feed Additives
}

\author{
Tiamiyu AM1*, Olatoye $\mathrm{IO}^{2}$ and Adedeji OB2 \\ ${ }^{1}$ Department of Biological Sciences, University of Medical Sciences, Nigeria \\ ${ }^{2}$ Department of Veterinary Public Health and Preventive Medicine, University of \\ Ibadan, Nigeria
}

*Corresponding author: Adebisi Tiamiyu, Department of Biological Sciences, University of Medical Sciences, P M B 536, Laje Road, Ondo City, Nigeria, Tel: +2348033121448; Email: tiaadebisi2014@yahoo.com

\section{Research Article \\ Volume 3 Issue 2}

Received Date: May 06, 2019

Published Date: June 10, 2019

DOI: $10.23880 /$ ijoac- 16000167

\section{Abstract}

Haematological components of blood are valuable in monitoring feed toxicity in cultured fish. The haematological and serum protein of the African Catfish (Clarias gariepinus) juvenile of both sex (n=84, mean weight $117.3 \pm 1.57 \mathrm{~g}$; mean length $26.70 \pm 0.26 \mathrm{~cm}$ ) fed with varying dietary inclusions level of Chromolaena odorata (Siam weed ) as feed additives for 42 days were determined. Four iso-nitrogenous (35\% crude protein) and nearly iso-caloric aqua feed were formulated with the locally sourced feed ingredients with $C$. odorata leaf powder introduced into the diets at graduated levels of $0.0 \%$ (control), $0.5 \%, 1.0 \%$ and $3.0 \%$ respectively. At the end of the feeding trial, blood samples were collected from three fish randomly selected from each replicate of the groups. Blood parameters such as red blood cell count (RBC), white blood cells count (WBC), lymphocytes, haematocrit, hemoglobin, mean cell volume (MCV), mean cell haemoglobin $(\mathrm{MCH})$ mean cell haemoglobin concentration (MCHC), plasma protein, albumin, globulin, A-G ratio and cholesterol were estimated. Statistical analysis revealed that these parameters were marginally different $(P>0.05)$ within the groups except WBC that were significantly lower $(\mathrm{P}<0.05)$ in treated groups compared with the control. However the values recorded for the parameters in all the groups were within haematological values recommended for cultured African Catfish. This suggests that the leaf powder of Chromolaena odorata fed as feed additives may be safe and non-toxic at low inclusion rates of 0.5 - 3.0\% and had no negative impact on the health status of the African Catfish.

Keywords: Blood Parameters; Clarias Gariepinus; Chromolaena Odorata; Dietary Inclusion Levels

Abbreviations: MCV: Mean Cell Volume; RBC: Red Blood Cell; MCH: Mean Cell Haemoglobin; MCHC: Mean
Cell Haemoglobin Concentration; EDTA: Ethylenediaminetetraacetic Acid; PCV: Packed Cell Volume; Hb: 


\section{International Journal of Oceanography \& Aquaculture}

Haemoglobin; WBC: White Blood Cells; SEM: Standard Error.

\section{Introduction}

The western region of Nigeria is endowed with rich vegetation and medicinal plants. The ethnic groups of the region have long experience in plant based traditional medicinal practices. All civilizations have always had traditions of using herbs to promote healing. Ates DA, et al. [1] reported that plants still remain the basis for development of modern drugs and medicinal plants have been used for years in daily life to treat diseases all over the world. According to Ayitey-Smith E [2] traditional medicine evolved from environmental resources, which the people of a community adapted in desperation for survival from disease. On the African continent, traditional medical practices date as far back as 4000 years. It was the sole medical system for health care before the advent of orthodox or modern medicine. Even in this present technological era, traditional medicine is still the predominant means in the third world for the preservation of health of the rural majority who constitute over $70 \%$ of the total population. Scientific reports had shown that leaves of plants are major sources of antioxidants, antimicrobials and phytochemicals with medicinal values [3,4]. Robinson $T$ [5] reported that plants produce compounds which have no apparent function in the primary metabolism of the plant and Tyler confirmed the extensive history of use of these compounds as therapeutic agents. Thus, some research workers, [6-8] advocated for the importance of characterizing different types of medicinal plants for their antioxidant and antimicrobial potential.

Numerous studies have shown that aromatic and medicinal plants are sources of diverse nutrient and nonnutrient molecules, many of which display antioxidant properties and can protect the animal and human body against both cellular oxidation reaction and pathogen. The medicinal values of these plants lie in their phytochemical components, which produce definite physiological actions on the human body and some research workers, Hill \& Phan TT, et al. [9] reported that the most important of these phytochemicals are alkaloids, tannins, flavonoids and phenolic compounds. Supplementation of the aqua feed with medicinal plants can reduce the excessive use of chemicals in aquaculture which can be a contributory factor towards development of antibiotic resistance which have been criticized $[10,11]$. Going by the popular saying 'let your food be your medicine and let your medicine be your food'. A number of plants have been continued to be investigated for their potential in supplementing animal diets for growth promotion and prevention of diseases. The greens (green plants of various sources) have long been recognized as the cheapest and most abundant potential source of proteins because of their ability to synthesize amino acids from a wide range of virtually unlimited and readily available primary materials such as water, $\mathrm{CO}_{2}$, atmospheric $\mathrm{N}_{2}$ (as in legumes) $[12,13]$.

Among these medicinal plants is Chromolaena odorata [(L) King and Robinson] belongs to the family Asteraceae, commonly known as Siam weed, is of neo-tropical origin. It was regarded as one of the worst weeds in the Old World tropics and subtropics $[14,15]$. Its common name in Southwestern, Nigeria includes 'Awolowo' 'Akintola' 'Independence weed' $[16,17]$. In traditional medicine, it is used as: antispasmodic, anti-protozoal, anti-trypanosomal, astringent, diuretic, hepatotropic, antifungal and antibacterial agents $[9,18]$. Nwokolo E [19] reported that proximate analysis of $C$. odorata showed that it could serve as a good source of energy, flavor, minerals, protein and dietary fibre thereby contributing to the palatability and supplementation of feed in animal nutrition. This may account for the usage of the plant in livestock production. Fasuyi AO, et al. [20] reported that dietary inclusion level of up to $5 \%$ of $C$. odorata in layers diet seemed to support a desirable health status as indicated in the haematological and biochemical parameters studied. However, much has not been done on usage of these medicinal plants in aquatic farming. In an experiment carried out on effect of $C$. odorata on growth performance of African Catfish (not yet published), it was discovered that growth parameters of African catfish fingerlings fed diet supplemented with $C$. odorata as feed additives improved growth performance of African Catfish fingerlings compared with the control. However, the effect of this medicinal plant on health status of the African Catfish is yet to be investigated.

Hematological parameters have been associated with health indices and have been employed in effectively monitoring the responses of organisms to stressors and thus its health status under such adverse conditions [21]. Fedato, et al. reported that haematological tests are used to establish normal health status and to diagnose diseases caused by various factors namely heavy metals, environmental stress, parasitic infections, and genotoxic effect of pollutants, nutrition, and pollution in human and veterinary science. Some research workers [22,23] pointed it out that haematological parameters were valuable tools for the monitoring of fish health. Although some research workers (Silveira and Rigores) also 


\section{International Journal of Oceanography \& Aquaculture}

reported that the standardization of haematological parameters is difficult in fish because these parameters can be influenced by deficient diets, diseases and environmental stress situations. Nevertheless, the analysis of these parameters may be used in monitoring the health status and improve the diagnosis of fish health $[24,25]$. This present study therefore explored the heamological and biochemical indices of African Catfish fed with varying levels of the leaf meal of $C$. odorata in their diets in order to elucidate more on its nutritional potentialities vis-a-vis its health status implication on African Catfish. It is also hoped that the publication will stimulate interest for further research in medicinal plants that can be useful in aquatic farming in view of abundant medicinal plants in our vicinity for the purpose of reducing chemical and hormones (which had been criticized for their negative impacts) used in aquatic farming to ensure food safety.

\section{Materials and Methods}

\section{Collection of Plant and Preparation of Plant Powder}

Fresh leaves of $C$. odorata were collected from their natural habitats in Southwestern University, Okun-owa environs, Ogun State, Nigeria in the month of September, 2014. The samples were identified and authenticated in the Department of Botany, University of Ibadan. The voucher specimen (UIH - 22521) was deposited in the University of Ibadan, herbarium. The plant was shade dried and grounded to fine powder using electric grinder.

\begin{tabular}{|c|c|}
\hline Phytochemicals & Chromolaena odorata \\
\hline Alkaloids & +++ \\
\hline Tannin & +++ \\
\hline Phlobatannin & ++ \\
\hline Saponin & +++ \\
\hline Flavonoids & + \\
\hline Anthraquinones & + \\
\hline Steroids & + \\
\hline Terpenes & - \\
\hline Cardenolides & +++ \\
\hline Phenol & - \\
\hline Chalcones & ++ \\
\hline Cardiac glycoside &
\end{tabular}

Observation Remarks:

$+++=$ Appreciable Amount Present,$++=$ Moderate Amount Present

$+=$ Trace Amount Present, - = Completely Absent

Table 1: Phytochemical analysis of Chromolaena odorata.

\begin{tabular}{|c|c|}
\hline Moisture (\%) & 9.26 \\
\hline Fiber (\%) & 15.28 \\
\hline Fat (\%) & 3.56 \\
\hline Protein (\%) & 18.86 \\
\hline Ash (\%) & 11.76 \\
\hline Carbohydrate (\%) & 41.28 \\
\hline
\end{tabular}

Table 2: Proximate analysis of Chromolaena odorata.

The phyto-qualitative (Table 1) and proximate analysis (Table 2) were carried out on the plant dried sample using standard procedure to identify the plant constituents as described by Harborne JB [26]; Trease GE, et al. and Sofowora A [27,28]. Plant extracts were analyzed chemically according to the official methods of analysis described by the Association of Official Analytical Chemist [29]. All analyses were carried out in duplicate.

\section{Experimental Diets}

C. odorata processed as earlier discussed was used as feed additive in the diet formulation. Other feed ingredients were purchased from reputable sources in Ibadan, Oyo State, Nigeria.

\begin{tabular}{|c|c|}
\hline Ingredients & $\mathbf{\%}$ \\
\hline Yellow corn & 35.0 \\
\hline Soybean meal (44\%) & 28.5 \\
\hline Fish meal (65\%) & 17.0 \\
\hline Wheat bran & 9.5 \\
\hline Calcium Carbonate & 0.3 \\
\hline Ground lime stone & 0.7 \\
\hline Vegetable Oil & 6.5 \\
\hline Mineral mixture & 1.7 \\
\hline Vitamin mixture & 1.0 \\
\hline Nutrients composition & $\mathbf{\%}$ \\
\hline Dry matter (DM) & 90.40 \\
\hline Crude protein (CP) & 30.65 \\
\hline Ether extract (EE) & 11.73 \\
\hline Ash & 2.70 \\
\hline Crude fiber & 10.11 \\
\hline Nitrogen free extract (NFE) & 44.81 \\
\hline Gross energy (Kcal/100 g DM) (GE)* & 467.77 \\
\hline Protein/energy (P/E) ratio (mg CP/Kcal GE)* & 65.52 \\
\hline
\end{tabular}

NFE (Nitrogen free extract) $=100-($ protein + lipid + ash + crude fibre). GE (Kcal/100 g DM) = CP x 5.64 + EE x 9.44 + NFE x 4.11 calculated according to NRC (1993), * not in percentage.

Table 3: Ingredients and Proximate Chemical Analysis (\% on dry matter basis) of the Experimental basal diet. 


\section{International Journal of Oceanography \& Aquaculture}

The results of the proximate compositions earlier determined were used in the eventual formulation of the different diets. Four iso-nitrogenous (35\% crude protein) and nearly iso-caloric aqua feed were formulated with the feed ingredients shown in Table 3. Diet 1 was the control diet without the $C$. odorata powder in the diet. Diets 2, 3 and 4 were formulated such that $C$. odorata was introduced into the diets at graduated levels of 0.5, 1.0 and $3.0 \%$ respectively.

\section{Management of Experimental Fish and Experimental Design}

Eighty four African Catfish juvenile of both sex (mean weight $117.3 \pm 1.57 \mathrm{~g}$; mean length $26.70 \pm 0.26 \mathrm{~cm}$ ) were sourced from a private fish farm at Olodo town in Oyo State, Nigeria. The fish were acclimatized for 14 days in 500L capacity circular tank fed with a locally formulated diet of $35 \%$ crude protein that did not contain herbal extract and no history of herbal feeding from the farm where fish were sourced. Afterward, they were randomly allotted into individual plastic tanks, replicated thrice under four dietary treatments. Seven fish were used per replicate making twenty one fish per treatment. The experimental fish were fed at their $5 \%$ body weight twice daily for forty two days. The water quality parameters were maintained within recommended limits according to recommendation of Boyd CE during this study [30].

\section{Blood Collection for Analysis}

At the end of the feeding trial, blood samples were collected from three fish randomly selected from each replicate with heparinized plastic syringe, fitted with 21 gauge hypodermic needle and preserved in disodium salt of ethylene-diaminetetraacetic acid (EDTA) bottles for analysis. The Blaxhall PC, et al. [24], Brown and Wedemeyer, et al. haematological methods were adopted for this study. The cyano-haemoglobin method was used to determine haemoglobin $(\mathrm{Hb})$ using diagnostic kits from Sigma diagnostics USA, and packed cell volume (PCV) was determined by the microhaematocrit method. Red blood cell (RBC) count was determined with the improved Neubauer haemocytometer according to Dacie JV, et al. [31]. White blood cells (WBC) was determined with the improved Neubauer counter, while differential counts such as neutrophils, lymphocytes and monocytes were determined on blood film stained with Giemsa stain. Mean corpuscular volume (MCV), mean corpuscular haemoglobin $(\mathrm{MCH})$ and mean corpuscular haemoglobin concentration (MCHC) were derived from the RBC, PCV and $\mathrm{Hb}$ using standard formulae [32]. MCV was calculated in femtoliters $=\mathrm{PCV} / \mathrm{RBC} \times 10, \mathrm{MCH}$ was calculated in picograms $=\mathrm{Hb} / \mathrm{RBC} \times 10$ and $\mathrm{MCHC}=(\mathrm{Hb}$ in $100 \mathrm{mg}$ blood / Hct) x 100. The serum proteins (measured in milligram per decilitre) were determined using spectrophotometer (Technicon, RA-1000, USA).

\section{Data Analysis}

All statistical analyses were performed with Graph Pad Prism statistical software Version 5.1. All data are presented as means with standard error (SEM). The data were analyzed with one-way ANOVA, and differences among mean values were considered significant at $\alpha<$ 0.05 with Tukey test used to compare differences among individual means (Figures 1-13).

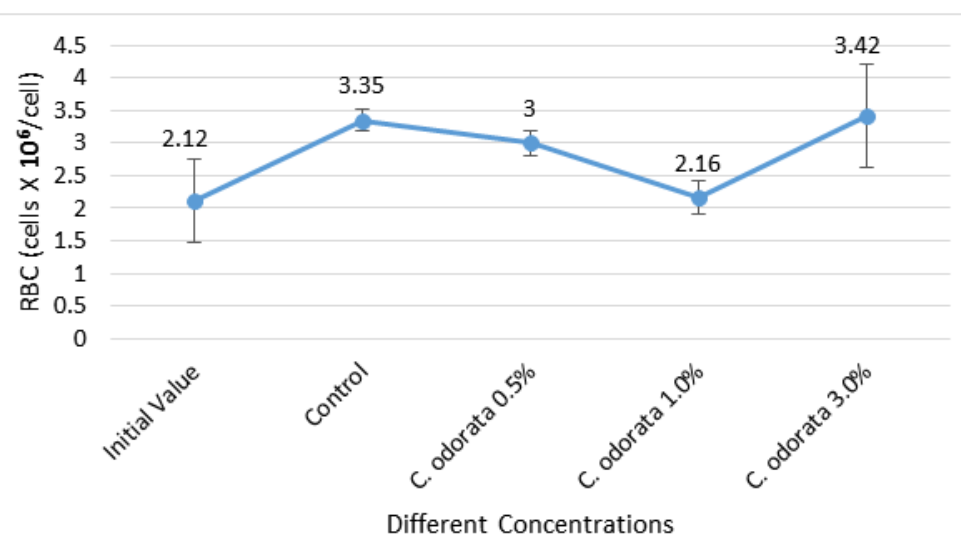

Figure 1: Red Blood Cells - RBC (cells $\times 10^{6} / \mathrm{L}$ ) of African Catfish fed different concentrations of $C$. odorata as feed additives. 


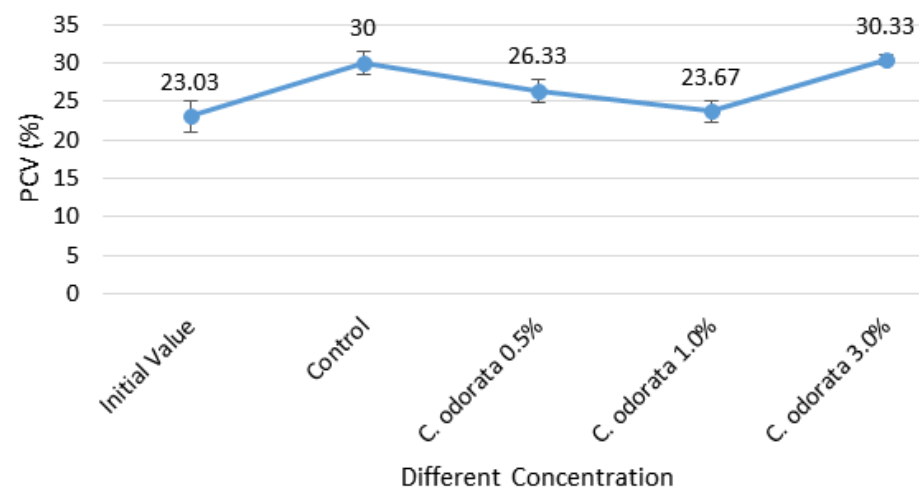

Figure 2: Packed Cell Volume - PCV (\%) of African Catfish fed different concentrations of $C$. odorata as feed additives.

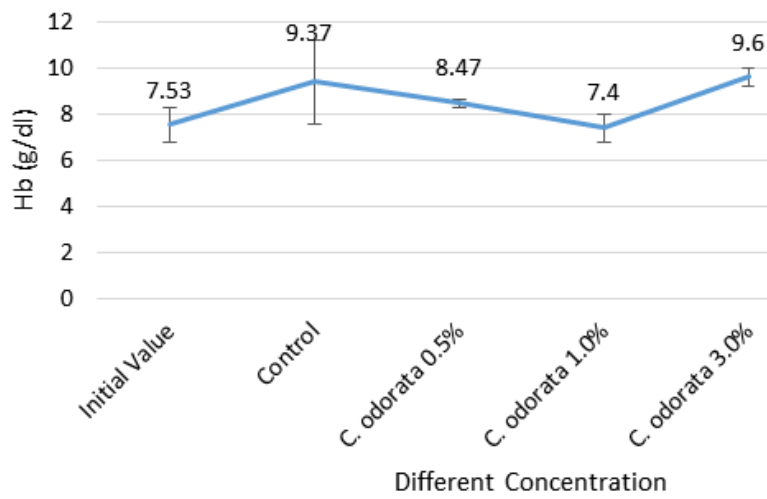

Figure 3: Haemoglobin Concentration - $\mathrm{Hb}(\mathrm{g} / \mathrm{dl})$ of African Catfish fed different concentrations of $C$. odorata as feed additives.

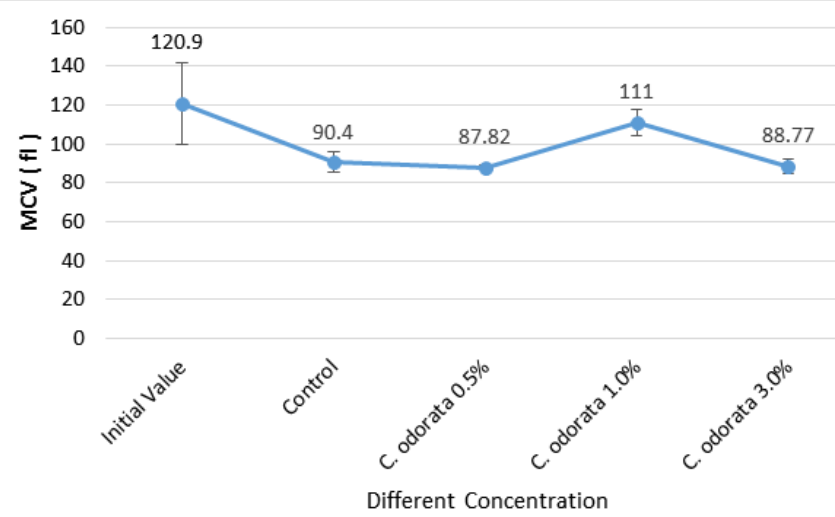

Figure 4: MCV (fl) of African Catfish fed different concentrations of $C$. odorata as feed additives. 


\section{International Journal of Oceanography \& Aquaculture}

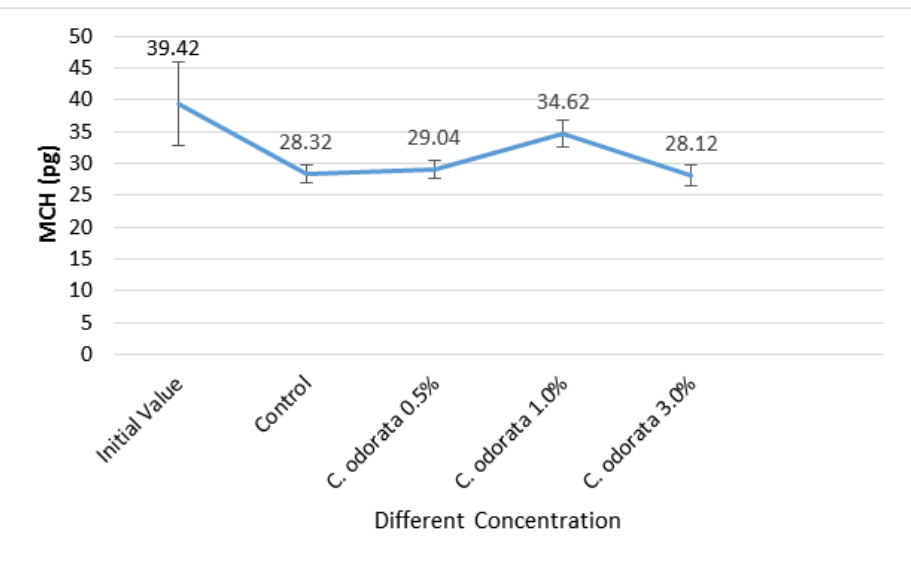

Figure 5: MCH (pg) of African Catfish fed different concentrations of $C$. odorata as feed additives.

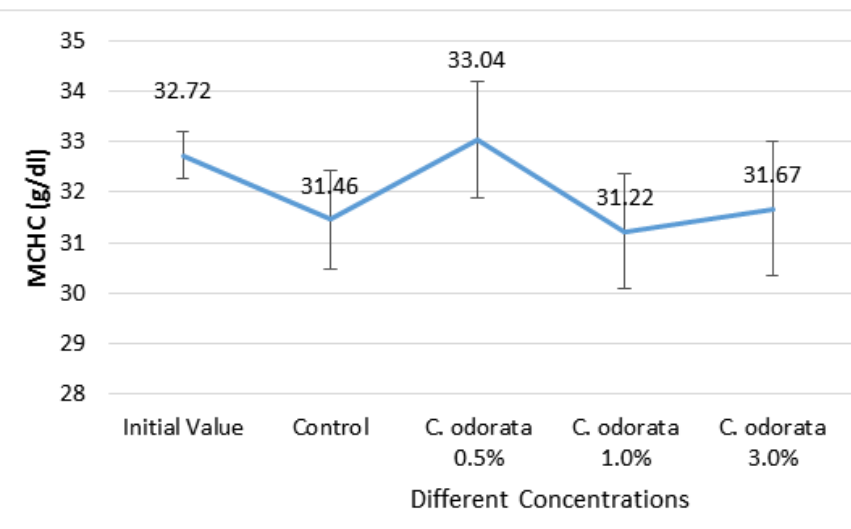

Figure 6: $\mathrm{MCHC}(\mathrm{g} / \mathrm{dl})$ of African Catfish fed different concentrations of $C$. odorata as feed additives.

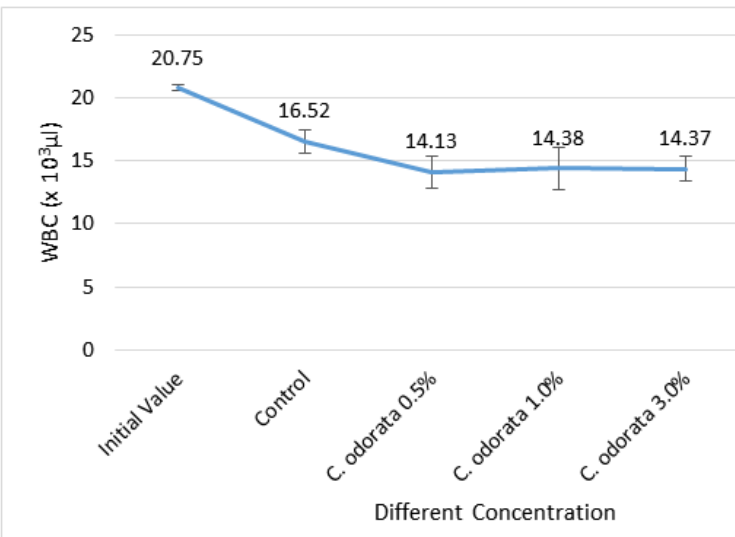

Figure 7: WBC $\left(\mathrm{x} 10^{3} \mu \mathrm{l}\right)$ of African Catfish fed different concentrations of $C$. odorata as feed additives. 


\section{International Journal of Oceanography \& Aquaculture}

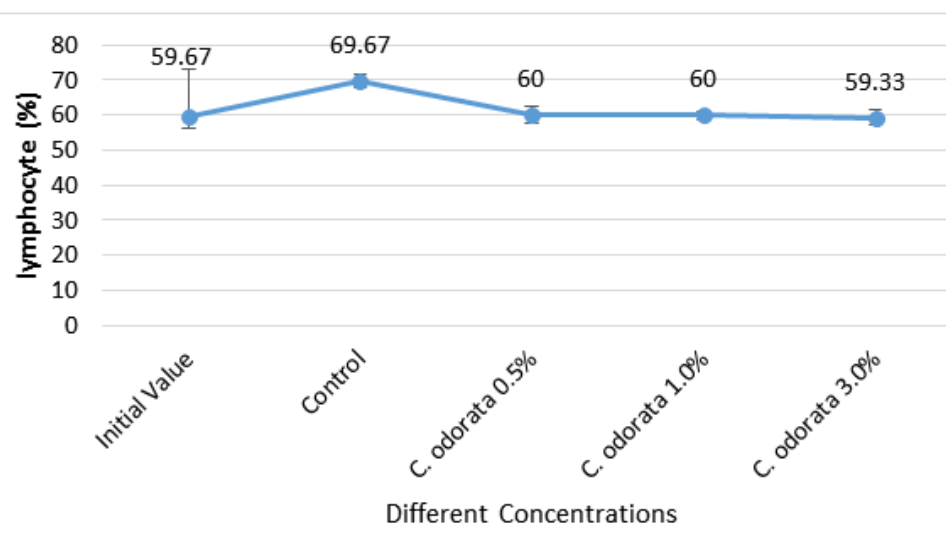

Figure 8: Lymphocyte (\%) of African Catfish fed different concentrations of $C$. odorata as feed additives.

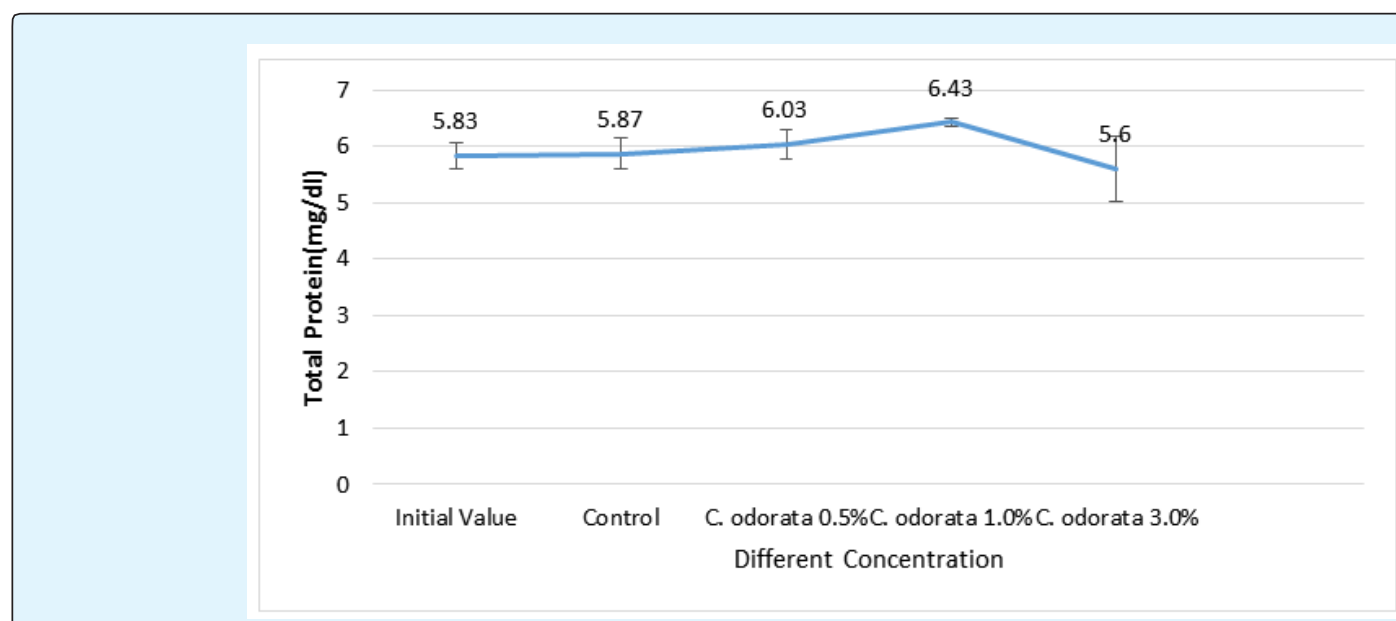

Figure 9: Total Protein (mg/dl) of African Catfish fed different concentrations of $C$. odorata as feed additives.

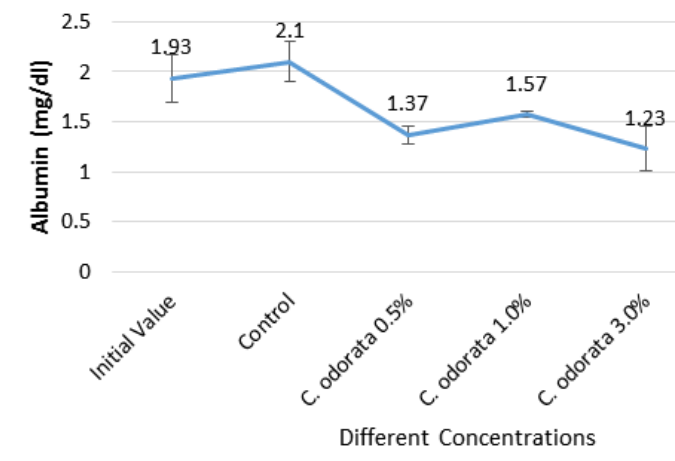

Figure 10: Albumin (mg/dl) of African Catfish fed different concentrations of $C$. odorata as feed additives. 


\section{International Journal of Oceanography \& Aquaculture}

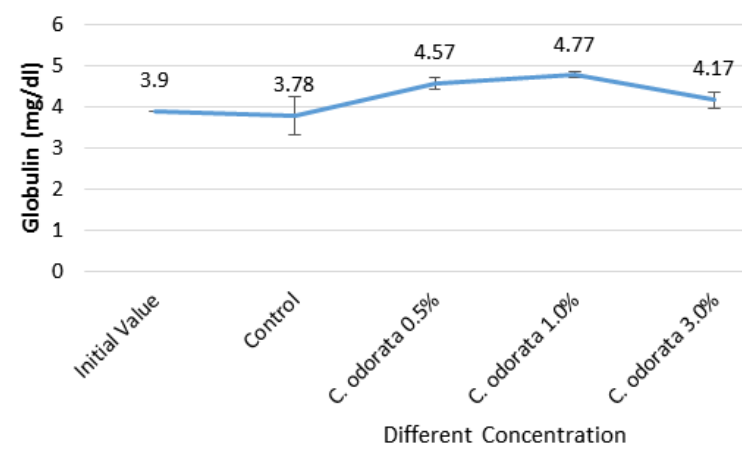

Figure 11: Globulin (mg/dl) of African Catfish fed different concentrations of $C$. odorata as feed additives.

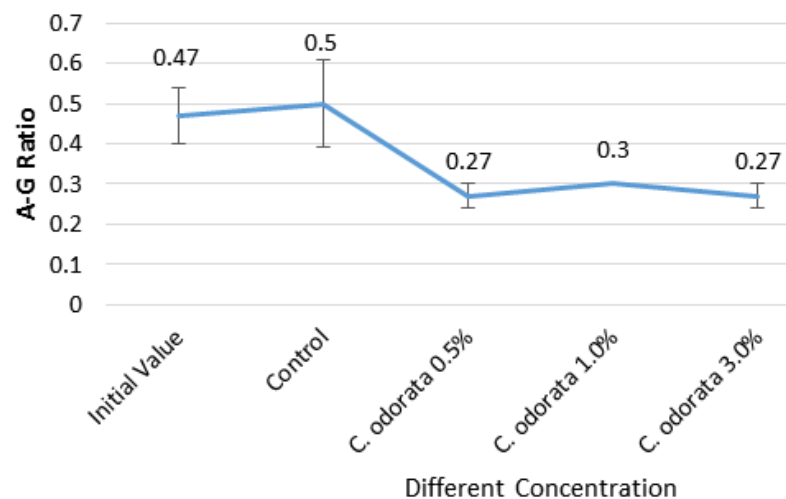

Figure 12: A-G Ratio of African Catfish fed different concentrations of $C$. odorata as feed additives.

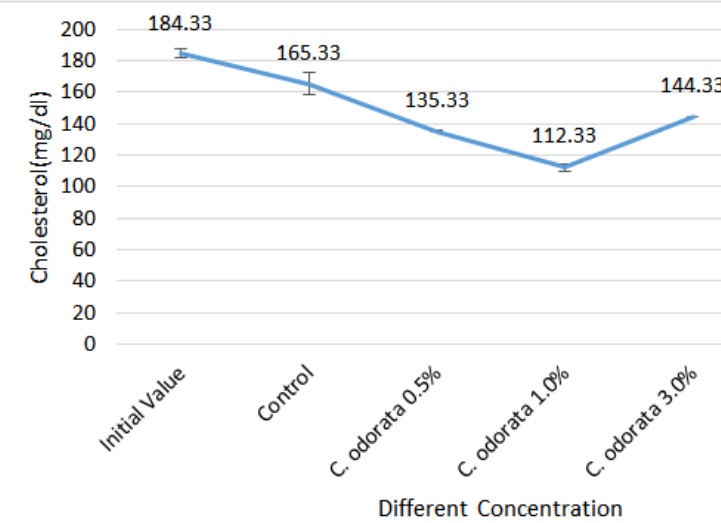

Figure 13: Cholesterol (mg/dl) of African Catfish fed different concentrations of $C$. odorata as feed additives. 


\section{International Journal of Oceanography \& Aquaculture}

\section{Results and Discussion}

The normal physiological regime of the fish body may be subjected to change, attributable to nutrition. Fedato et al. reported that the nutritive status of fish can be linked to their health condition and potential way they deal with stress resulting from their surrounding environment. Previous haematological studies of nutritional effects brought the knowledge that erythrocytes, PCV and $\mathrm{Hb}$ are the major and reliable indicators of various sources of stress [33] and these parameters decrease in the presence of anti-nutritional factors [34]. Oyawoye EO, et al. [35] pointed out that haematological components of blood are valuable in monitoring feed toxicity especially with feed constituents that affect the formation of blood in culture fisheries. The red blood cells count (RBC), haematocrit (PCV) and haemoglobin ( $\mathrm{Hb})$ concentration vary with diet as well as temperature, season of the year and nutritional status of the fish.

The erythrocytes count ranged between $2.16-3.42$ $\mathrm{x} 10^{6} \mu \mathrm{l}$ (Figure 1) recorded in this experiment is within the range of $\left(2.3-2.9 \times 10^{6} \mu \mathrm{l}\right)$ and $\left(1.5 \times 10^{6} \mu \mathrm{l}\right)$ described for catfish by Gabriel UU, et al. and Adeyemo 0, et al. respectively $[36,37]$. The highest value of $3 \cdot 42 \times 10^{6} \mu \mathrm{l}$ recorded for group of fish fed with $30 \mathrm{~g} / \mathrm{kg}$ of C. odorata was similar to observations noted by Dada AA, et al. [38] who recorded the value of $3.50 \pm 0.35 \times 10^{6} \mu \mathrm{l}$ when ethanoic extracts of Garcinia kola seeds were fed to Clarias gariepinus brood stock. In this present study, values recorded could be due to higher activity displayed by the fish as explained by Svobodova Z, et al. [39] who reported that active species displayed high haematological parameters values when compared to low active species. RBC is the dominant cell type in the blood of the majority of fish species and low values suggesting low activity of cultured fish [39].

Regarding the hematocrit values in this present experiment there was no significant difference $(\mathrm{P}>0.05)$ in the values recorded within the group when compared with control treatment however highest value of $30.33 \pm 0.667 \%$ was recorded in the group of fish fed on $30 \mathrm{~g} / \mathrm{kg}$ of of C. odorata (D3) while lowest value $(23.67 \pm 1.45 \%)$ of hematocrit was obtained in group of fish fed on $10 \mathrm{~g} / \mathrm{kg}$ of $C$. odorata (D2). The values observed in the treated fish were within the normal range of haematocrit for African Catfish as reported by some workers $[40,41]$ that normal values were usually range between $20 \%$ and $35 \%$ and rarely attain greater than $50 \%$. These values observed were also within the range reported by some researchers [42] for Heterobranchus longifillis young adults raised in Umudike, South East, Nigeria.

Haemoglobin levels observed in this experiment were marginally different $(\mathrm{P}>0.05)$ in treated fish with highest value of $9.60 \pm 0.379 \mathrm{~g} / \mathrm{dl}$ and lowest values of $7.40 \pm 0.0611 \mathrm{~g} / \mathrm{dl}$ recorded in the group of fish fed D3 and D2, respectively. Haemoglobin has the physiological function of transporting oxygen to tissues of the animal for oxidation of ingested food so as to release energy for the other body functions as well as transport carbon dioxide out of the body of animals [43-46]. In this experiment, no significant difference in $\mathrm{Hb}$ concentration was observed in fish fed $C$. odorata as feed additive when compared with control, however, the $\mathrm{Hb}$ concentration values observed in this experiment were similar to what were observed by Omitoyin BO [47] when African catfish juvenile were fed poultry litter. The results were also similar to what were obtained by Osuigwe SI, et al. [34] when fed fenugreek Clarias gariepinus with Jackbean meal based diets. Mohan A, et al. [48], reported values as low as $5.47-5.68 \mathrm{~g} / \mathrm{dl}$ in three commercially important freshwater fishes captured in river Cauvery Velur, Namakkal district, Tamil Nadu, India. Some workers [4951] explained that the low $\mathrm{Hb}$ values could be associated with low active fishes. Blaxhall PC, et al. [24] reported the essence of using haematocrit to detect anaemic condition in fishes. In addition to the Packed Cell Volume (PCV), or hematocrit and actual number of red cells present in circulating blood, certain comparative measurements are also used to differentiate the various types of anaemia. These are the mean corpuscular volume (MCV), or the average volume of erythrocytes expressed in cubic microns or $\mathrm{fl}$, the mean corpuscular heamoglobin $(\mathrm{MCH})$, or the haemoglobin content of the erythrocytes expressed in microns or pg; and mean corpuscular haemoglobin concentration (MCHC), or the concentration of haemoglobin expressed in percent or $\mathrm{g} / \mathrm{dl}$ and these were calculated from obtained hematological data. In this present study, highest values of $111.0 \pm 6.73 \mathrm{fl}, 34.62 \pm 2.14$ pg and $33.04 \pm 1.15 \%$ were recorded for $\mathrm{MCV}, \mathrm{MCH}$ and MCHC respectively. The mean corpuscular volume (MCV) range recorded in this experiment was higher than 79.20 to $105.32 \mathrm{fl}$ reported for Heteroclarias [52], meanwhile the mean corpuscular haemoglobin concentration (MCHC) recorded in this study compared fairly well with $30.70 \%$ reported for C. gariepinus from Asejire dam [53] and also within the range of 30 to $66 \%$ reported by Mohan A, et al. [48]. The $\mathrm{MCH}$ values obtained in this study was higher than the range 20.82 to $26.60 \mathrm{pg}$ reported for Hetero clarias fed Carica papaya leaf meal incorporated feed [52]. All the values of erythrocytes, PCV and $\mathrm{Hb}$ observed in 


\section{International Journal of Oceanography \& Aquaculture}

this study were within the recommended physiological ranges reported for $C$. gariepinus as reported by some workers cited an indication that $C$. gariepinus are tolerant to $C$. odorata at $0.5 \%, 1.0 \%$ and $3.0 \%$ concentration. Minor variations observed could be due to effect of bioactive compounds of the plant on the fish, environmental conditions or management techniques.

The results of White blood cells (WBC) recorded in this experiment ranged from $14.13 \pm 1.272 \times 10^{3} \mu \mathrm{l}$ in group of fish fed $5 \mathrm{~g} / \mathrm{kg}$ C. odorata to $14.38 \pm 1.653 \times 10^{3} \mu \mathrm{l}$ in group of fish fed $10 \mathrm{~g} / \mathrm{kg} \mathrm{C}$. odorata and the values recorded were significantly lower $(\mathrm{P}<0.05)$ compared with the value of $16.52 \pm 0.956 \times 10^{3} \mu$ observed in group of fish fed without $C$. odorata additives. However, the values observed were higher than the highest value of $7.90 \times 10^{3} \mu \mathrm{l}$ recorded for WBC in fish fed diet containing $50 \%$ M. olifera leaf meal [54].The lymphocyte count recorded ranged from $59.33 \pm 2.333 \%$ to $69.67 \pm 1.801 \%$ with highest value observed in the control group. White blood cells (WBC) and lymphocytes are the defense cells of the body. Douglas JW, et al. [54] demonstrated that the amount has implication in immune responses and the ability of the animal to fight infection. The primary function of WBC's is to defend the body against foreign pathogenic organisms The major functions of the white blood cell and its differentials are to fight infections, defend the body by phagocytosis against invasion by foreign organisms and to produce or at least transport and distribute antibodies in immune response. Thus, animals with low white blood cells are exposed to high risk of disease infection, while those with high counts are capable of generating antibodies in the process of phagocytosis and have high degree of resistance to diseases [45] and enhance adaptability to local environmental and disease prevalent conditions $[46,55,56]$. There is wide range in reported number of total leukocytes in apparently normal African Catfish. In this present study, WBC counts were within the range recorded for normal African Catfish. This result agrees with the findings of Ndong D, et al. [57] who reported that WBC counts increased significantly in juvenile hybrid tilapia fish fed $1 \%$ and $0.5 \%$ garlic supplemented diet. High WBC count is usually associated with microbial infection or the presence of foreign body or antigen in the circulating system [35]. The values, range from 14.13× $10^{3} \mu \mathrm{l}$ to $14.38 \times 10^{3} \mu \mathrm{l}$ recoded in this study were higher than what were reported by Dienye HE, et al. [58] who reported range of $7.20 \times 10^{3} \mu \mathrm{l}$ to $8.02 \times 10^{3} \mu \mathrm{l}$ when Moringa Oleifera leaf meal was fed to African Catfish and value obtained were not up to $41.1 \pm 11.05 \times 10^{3} \mu \mathrm{l}$ referenced by Erhunmwunze NO, et al. [59] when some blood parameters of African catfish were characterized. The difference observed could be due to different in age of experimental fish, effect of the feed additives and/or environmental conditions.

The biochemical analyses can be also used to detect the health of fish $[60,61]$. In this study, the level of plasma protein observed in all the groups range from 5.60 $\pm 0.58 \mathrm{mg} / \mathrm{dl}$ to $6.03 \pm 0.27 \mathrm{mg} / \mathrm{dl}$. The level of Plasma protein observed were marginally different $(\mathrm{P}>0.05)$ among the treated fish. This finding is within the range of earlier reports that total plasma protein in fish could vary from 2-8gd-1 [62]. The globulin and albumin values are related, in that the two are combined to know the level of protein in the blood stream [63]. Values, which are lower or higher than the normal ranges indicate serious health conditions. According to Omitoyin OB [64], a significant increase in the values of plasma electrolyte of sodium, chloride, phosphate: excretory products of urea and creatinine; globulin and albumin/globulin ratio are suggestible of abnormal physiological function of metabolism in fish. The values obtained for albumin and globulin in this present study were within the normal ranges for C. gariepinus as reported by Adams SM, et al. [65] who reported the normal range for total protein to be between $3-6 \mathrm{mg} / 100 \mathrm{ml}$ but slightly above $3.8 \mathrm{mg} \pm$ $0.11 \mathrm{mg} / 100 \mathrm{ml}$, reference value reported by Adeyemo 0, et al. [37] normal range for total protein to be between $3 \mathrm{~g}-6 \mathrm{mg} / 100 \mathrm{ml}$ but slightly above $3.8 \mathrm{mg} \pm 0.11 \mathrm{mg} / 100$ $\mathrm{ml}$, reference value reported by Adeyemo 0, et al. [37]. The increase in the serum protein, albumin and globulin contents recorded in group of fish fed with $10 \mathrm{~g} / \mathrm{kg} C$. odorata reflect strong innate immunity as described by Jha AK, et al. [66]. These findings are in agreement with the finding of Nya EJ, et al. [67] and this suggested that $C$. odorata and included at rate of $0.5-1.0 \%$ improved the immune response of African Catfish. The value of Cholesterol 112.33 \pm 2.33 observed in the group of fish fed with $10 \mathrm{~g} / \mathrm{kg}$ C. odorata decreased significantly $(\mathrm{P}<0.05)$ compared with control group with $165.33 \pm 6.78$. No mortality was recorded throughout the duration of the experiment and this should allay the fear of death following the consumption of $C$. odorata by fish. This might not be unconnected with the reduction of the antinutrient factors in the leaves by air-drying.

\section{Conclusion}

This investigation revealed that $0.5-1.0 \%$ C. odorata fed as feed additive in diet of African Catfish (C. gariepinus) juveniles had no adverse toxicological effect on the fish as proved through the haematological indices. Use of $C$. 


\section{International Journal of Oceanography \& Aquaculture}

odorata as feed additives could also reduce feed cost to the fish farmer, whose most important production cost comes from feed. It is expected that this result will stimulate a series of studies on the utilization of medicinal plants as feed additives in diets for fishes. In the last decade, there is increased public aware-ness on detrimental effect of antibiotics to human consumers as a result of emergence of antibiotics resistant bacterial strains and antibiotics residue in food fish, led to banning of the use of antibiotics as growth promoters in aquaculture diets in advanced countries of the world.

\section{Acknowledgment}

We would like to express our deepest thanks to all staff of F. M Sanusi Aqualife Farms, Olodo Ibadan, Oyo State, Nigeria for providing Specimens used in this study and technical advice. Also our profound gratitude goes to Technical Staff of Department of Pathology (Clinical Pathology Unit), Faculty of Veterinary Medicine, University of Ibadan, Ibadan, Nigeria for their cooperation and technical assistance.

\section{References}

1. Ates DA, Erdogrul OT (2003) Antimicrobial activities of various medicinal and commercial plant extracts. Turk J Biol 27: 157-162.

2. Ayitey Smith E (1989) Prospects and Scope of Plant Medicine in Health Care. Ghana Universities Press Accra pp: 1-2.

3. Obadoni BO, Ochuko PO (2002) Global J Pure Appl Sci 8(2): 203-208.

4. Nabavi SM, Ebrahimzadeh MA, Nabavi SF, Hamidinia AA, Bekhradnia AR (2008) Pharmacology online (2): 560-567.

5. Robinson $T$ (1991) The Organic Constituents of higher plants. $6^{\text {th }}$ (Edn.), Cardus Press, North Amherst, Massachusetts.

6. Mothana RAA, Lindequist U (2004) Antimicrobial activity of some medicinal plants of the island Soqotra. J Ethnopharmacology 96(1-2): 177-181.

7. Bajpai M, Pande A, Tewari SK, Prakash D (2005) Phenolic contents and antioxidant activity of some Food and medicinal plants. Int J Food Sci Nutr 56(4): 287-291.
8. Wojdylo A, Oszmianski J, Czemerys R (2007) Antioxidant activity and phenolic compounds in 32 selected herbs. Food Chemistry 105(3): 940-949.

9. Phan TT, Wang L, See P, Grayer RJ, Chan SY, et al. (2001) Phenolic compounds of Chromolaena odorata protect cultured skin cells from oxidative damage: implication for cutaneous wound healing. Biol Pharm Bull 24(12): 1373-1379.

10. Adedeji OB, Tiamiyu AM, Emikpe BO (2011) The Antibiotic Resistance Pattern of Bacterial Flora of Fish from Different Aquatic Environments from Ibadan, South West Nigeria. J Environ Biol 5(8): 2039-2047.

11. Tiamiyu AM (2016) Bacterial Flora of Wild and Cultured Clarias gariepinus (African Catfish) and their Public Health Implications. Adv Biomed Pharma 3(1): 138-145.

12. Oke OL (1973) The mode of cyanide detoxification. In: Mclntrye E \& Nestle C (Eds.), Chronic Cassava toxicity.

13. Fasuyi AO, Aletor VA (2005) Protein replacement value of cassava (Manihot esculenta, Crantz) leaf protein concentrate (CLPC) in broiler starter: effect on performance, muscle growth, haematology and serum metabolites. Int J Poult Sci 4(5): 339-349.

14. Holm LG, Plucknett DL, Pancho JV, Herberger JP (1977) The World's Worst Weeds. Distribution and Ecology. University Press of Hawaii, Honolulu.

15. Zachariades C Day, Muniappan MR, Reddy GVP (2009) Chromolaena odorata (L.) King and Robinson (Asteraceae). Biological Control of Tropical Weeds Using Arthropods. In: Muniappan R, et al. (Eds.), Cambridge University Press, UK, pp: 130-160.

16. Okon PB, Amalu UC (2003) Using weed to fight weed. Leisa Magazine.

17. Ngozi N, Osuji T (2014) Personal communication on the relevance and indigenous use of medicinal plants.

18. Akinmoladun EO, Ibukun EO, Dan-Ologe IA (2007) Phytochemcial constituents and antioxidant properties of extracts from the leaves of Chromolaena odorata. Sci Res Essay 2(6): 191-194.

19. Nwokolo E (1987) Leaf meal of cassava (Manilot esculenta crantz) and Siam weed (C. odorata) as 


\section{International Journal of Oceanography \& Aquaculture}

nutrient sources in poultry diets. Nutri Rep Int 36: 819-826.

20. Fasuyi AO, Fajemilehin SOK, Aro SO (2005) Nutritional potentials of Siam weed (Chromolaena odorata) leaf meal (SWLM) on laying hens: biochemical and haematological implications. Pakistan Journal of Nutrition 4(5): 336-341.

21. Saliu JA, Elekofehinti 00, Komolafe K, Oboh G (2012) Effects of some green leafy vegetables on the Hematological parameters of Diabetic Rats. Scholars Research Library. J Nat Prod Plant Resource 2(4).

22. Bhaskar BR, Rao KS (1984) Influence of environmental variables on haematological ranges of milk fish, Chanos chanos (forskal), in brackish-water culture. Aquaculture 83: 123-136.

23. Schuett DA, Lehmann J, Guerlich R, Hamers R (1997) Haematology of Swordtail xiphiphorus helleri. I: Blood parameters and light microscopy of blood cells. J Appl Icthiyol 13: 83-89.

24. Blaxhall PC, Daisley KW (1973) Routine hematological methods for use with fish blood.

25. Anderson DP, Siwicki AK (1994) Duration of protection against Aeromonas salmonicida

26. Harborne JB (1973) Phytochemical methods. $3^{\text {rd }}$ (Edn.), Chapman \& Hall Ltd, London, pp: 135-203.

27. Trease GE, Evans WC (1989) Pharmacognosy. $13^{\text {th }}$ (Edn.), Balliere Tindall, London, pp: 882.

28. Sofowora A (1993) Medicinal plants and traditional medicines in Africa. Chichester John Wiley \& Sons, New York, pp: 97-145.

29. AOAC International Official Methods of Analysis (2005) $18^{\text {th }}$ (Edn.), AOAC International,

30. Boyd CE (1999) Water Quality in Warm Water Fish Ponds. Craft Master Printers, Inc. Opelika, Alabama, USA, pp: 359.

31. Dacie JV, Lewis SN (1991) Practical Haematology, $5^{\text {th }}$ (Edn.), Churchhill Livingstone, Edinburgh. pp: 390.

32. MAFF (1984) Ministry of Agriculture and Food Manual of Veterinary Investigation-Laboratory Techniques Volume 2 Reference Book 390. $3^{\text {rd }}$ (Edn.), In: Davies ET, et al.
33. Rainza Paiva MJT, Ishikawa CM, Dostiras AA, Felizando NN (2000) Haematological raised in fresh water pond in Nigerian. Journal of Applied Ichthyology 9(3-4): 250-256.

34. Osuigwe DI, Nwosu C, Ogunji JO (2007) Preliminary Observations on some Haematological Parameters of Juvenile Heterobranchus longifilis fed different dietary Levels of Raw and Boiled Jackbean (Canavalia ensiformis) Seed Meal. Tropentag University of Kassel-Witzenhausen and University of Göttingen, October 9 - 11, 2007 Conference on International Agricultural Research for Development. pp: 1-6.

35. Oyawoye EO, Ogunkunle M (1998) Physiological and biochemical effects of raw Jack beans on broilers. Proc Ann Conf Nig Soc Anim Prod 23: 141-142.

36. Gabriel UU, Ezeri GNO, Opabunmi OO (2004) Influence of sex, source, health status and acclimation on the haematology of Clarias gariepinus (Bruchell 1822). African Journal of Biotech 3(9): 163-467.

37. Adeyemo O, Agbede SA, Olaniyan AO, Shoaga OA (2003) The haematological response of Clarias

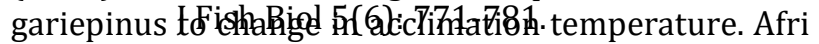
J Biomed Res 6(2): 105-108.

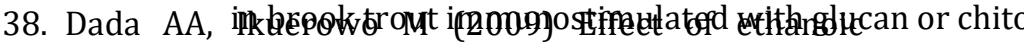
extracts of Garcinia kola seeds on growth and haematology of catfish (Clarias gariepinus) broodstock. African Journal of Agricultural Research 4(4): 344-347.

39. Svobodova Z, Kroupova H, Modra H, Flajshans M, Randak T, et al. (2008) Haematological profile of common carp spawners of various breeds. J Appl Ichthyol 24: 55-59.

40. Erondu ES, Nnubia S, Nwanukwe FO (1993) Haematological studies on four catfish species raised in fresh water pond ipt Nigeria. Journal of Applied Ichthyology 9(3-4): 250-256.

41. Adeyemo BT, Obande R A, Solomon SG (2014) Haematological reference ranges of cultured Clarias gariepinus in the lower Benue River Basin, Nigeria. Comparative Clinical Pathology 23(2): 361-366.

42. Okorie-Kanu CO, Unakalamba NJ (2014) Haematological and Blood Biochemistry Values of Cultured Heterobranchus longifilis in Umudike, Abia 


\section{International Journal of Oceanography \& Aquaculture}

State, Nigeria. Animal Research International 11(2): 1987-1993.

43. Ugwuene MC (2011) Effect of Dietary Palm Kernel Meal for Maize on the Haematological and Serum Chemistry of Broiler Turkey. Nigerian Journal of Animal Science 13: 93-103.

44. Omiyale CA, Yisa AG, Ali-Dunkrah LA (2012) Haematological characteristics of Yankasa sheep fed fonio (Digitaria iburua) straw based diets, Proceedings of $37^{\text {th }}$ Annual Conference of Nigerian Society for Animal Production pp: 87-89.

45. Soetan KO, Akinrinde AS, Ajibade TO (2013) Preliminary studies on the haematological parameters of cockerels fed raw and processed guinea corn (Sorghum bicolor), Proceedings of $38^{\text {th }}$ Annual Conference of Nigerian Society for Animal Production, pp: 49-52.

46. Isaac LJ, Abah G, Akpan B, Ekaette IU (2013) Proceedings of the 18th Annual Conference of Animal Science Association of Nigeria, pp: 24-27.

47. Omitoyin BO (2006) Haematological changes in the blood of Clarias gariepinus (Burchell 1822) juvenile fed poultry litter. Livestock research for rural development 18(11): 1-6.

48. Mohan A, Senthilkumar D (2016) Assessment of the haematological and serum biochemical parameters of three commercially important freshwater fishes in river Cauvery Velur, Namakkal district, Tamil Nadu, India. International Journal of Fisheries and Aquatic Studies 4(1): 155-159.

49. Engel DW, Davis EM (1964) Relationship between activity and blood composition in certain marine teleost. Copeia 3: 586-587.

50. Rambhaskar B, Srinivasa Roa K (1986) Comparative hematology of ten species of marine fish from Visakhapatnam Coast. J Fish Biol 30: 59-66.

51. Satheeshkumer P, Ananthan G, Kumar SD, Jagadeesan L (2011) Haematology and biochemical parameters of different feeding behaviour of teleost fishes from Vellar estuary, India. Comparative Clinical Pathology 21(6): 1187-1191.

52. Anyanwu DC, Udedibie ABI, Osuigwe DI, Ogwo VO (2011) Haematological responses of hybid of
Heterobranchus bidorsalis x Clarias gariepinus fed dietary levels of Carica papaya leaf

53. Adedeji OB, Adegbile AF (2011) Comparative haematological parameters of the Bagrid catfish (Chrysichthys nigrodigitatus) and African catfish (Clarias gariepinus) from Asejire Dam Southwestern Nigeria. J Appl Sci Res 7(7): 1042-1046.

54. Douglas JW, Jane KW (2010) In Schalm's Veterinary Haematology. John Wiley and Sons, Blackwell publishing Ltd. pp: 1232.

55. Okunlola DO, Olorunisomo AO, Aderinola AO, Agboola AS, Omole OG (2012) Haematology and serum quality of red Sokoto goats fed Baobab (Adansonia digitata) fruit meal as supplement to guinea grass (Panicum maximum), Proceedings of the $17^{\text {th }}$ Annual Conference of Animal Science Association of Nigeria. pp: 427-433.

56. Iwuji TC, Herbert U (2012) Haematological and serum biochemical characteristics of rabbit bucks fed diets containing garcimiola kola seed meal, Proceedings of $37^{\text {th }}$ Annual Conference of Nigerian Society for Animal Production pp: 87-89.

57. Ndong D, Fall J (2007) The effect of garlic (Allium sativum) on growth and immune responses of hybrid tilapia (Oreochromis niloticus $x$ Oreochromis aureus) ASFA/Fisheries biology 5: 3-11.

58. Dienye HE, Olumuji OK (2014) Growth performance and haematological responses of African mud catfish Clarias gariepinus fed dietary levels of Moringa oleifera leaf meal. Net Journal of Agricultural Science 2(2): 79-88.

59. Erhunmwunze NO, Ainerua MO (2013) Characterization of Some Blood Parameters of African Catfish (Clarias gariepinus) Ainerua AmericanEurasian. Journal of Toxicological Sciences 5(3): 7276.

60. De-Pedro N, Guijarro AE, Lopez-Patino MA, MarinezAlvarez R, Delgado M (2005) Daily and seasonal variation in haematological and blood biochemical parameters in tench Tinca tinca Linnaeus, 1758. Aquaculture Res 36(12): 1185-1196.

61. Martins MBG, Castro AA, Cavalheiro AJ (2008) Caracterizacao anatomica e quimica de folhas de 


\section{International Journal of Oceanography \& Aquaculture}

Jacaranda puberula (Bignoniaceae) presente na Mata Atlantica. Rev Bras Farmacogn 18(4): 600-607.

62. Ravi SP, Jitender KN (2005) Fish Biology and Ecology Theory: Circulatory system of fish. University College of Sciences, Osmania University, Hyderabad, pp: 347.

63. Uyanik F, Eren M, Afasever TG, Kolsuz AH (2001) Changes in some biochemical parameters and organs of broilers exposed to cadmium and effect of zinc on cadmium induced alterations. Israel Journal of Veterinary Medicine 56: 128-134.

64. Omitoyin OB (2007) Introduction to fish farming in Nigeria printed by royal Bird ventures Mushin-Lagos pp: $1-50$.
65. Adams SM, Brown AM, Goede RW (1993) A quantitative health assessment Index for rapid evaluation of fish condition in the field. T Am Fish Soc 122(1): 63-73.

66. Jha AK, Pal AK, Sahu NP, Kumar S, Mukherjee SC (2007) Haemato-immunological responses to dietary yeast RNA, omega-3 fatty acid and carotene in Catla catla juveniles. Fish Shellfish Immunol 23(5): 917927.

67. Nya EJ, Austin B (2009) Use of garlic, Allium sativum, to control Aeromonas hydrophila infection in rainbow trout, Oncorhynchus mykiss (Walbaum). J Fish Dis 32(11): 963-970. 